\title{
EL PROCEDIMIENTO MONITORIO EN EL ANTEPROYECTO DE CÓDIGO PROCESAL CHILENO. \\ ALGUNAS CONSIDERACIONES A PARTIR DE LA EXPERIENCIA EN DERECHO ESPAÑOL
}

\section{JOSÉ BONET NAVARRO*}

RESUMEN: El autor trata, desde su experiencia como profesor y juez en España, las características del proceso monitorio en el anteproyecto de código procesal civil chileno. En este análisis se realiza primero un estudio sistemático del ACPC, y enseguida se analiza críticamente el anteproyecto dejándose en evidencia sus vacios e imperfecciones. Con ello, y sobre todo al especificarlas, contribuye precisa y claramente a mejorarlo.

Palabras Clave: Anteproyecto - Código procesal - Proceso monitorio - Título ejecutivo.

\section{THE ADMONITORY PROCEEDINGS IN THE CHILEAN PROCEDURAL CODE DRAFT BILL.}

\section{SOME CONSIDERATIONS BASED ON THE SPANISH LAW EXPERIENCE}

ABSTRACT: The author deals with the characteristics of the admonitory proceedings in the Chilean civil procedural code draft bill, from his experience as a professor and judge in Spain. He first does a systematic study of this draft bill, and then critically analyzes it finding loopholes and imperfections. By doing this, and because be specifies them, be contributes clearly and precisely to improve it.

KEY WORDS: Draft bill - Procedural code - Admonitory proceedings - Executory title.

SUMARIO: I. Consideraciones preliminares. II. Concepción y naturaleza jurídica del procedimiento monitorio en el ACPC. 1. La indefinición en el texto del ACPC. 2. Una forma de entender y aprovechar el proceso monitorio: A) Eficacia de cosa juzgada cuando el proceso finalice por falta de pago u oposición.

Profesor Titular de Derecho Procesal, Universitat de Valencia (EsPañA). Magistrado Suplente de la Audiencia Provincial de Valencia (EsPAÑA). Correo electrónico: jose.bonet@uv.es Fecha de recepción: 12 de mayo de 2007

Fecha de aceptación: 8 de junio de 2007 
B) Vinculación e intima conexión de la oposición del deudor con el eventual proceso ulterior para sustanciarla. III. Consideraciones sobre algunos aspectos buérfanos de atención expresa. 1. La alegación de la "falta de jurisdicción, incompetencia del tribunal o existencia de compromiso": A) La declinatoria en el seno del procedimiento monitorio y en relación con el procedimiento posterior a la oposición. B) La "falta de jurisdicción, incompetencia del tribunal o existencia de compromiso" como excepción de carácter procesal. 2. Ausencia de referencia expresa al pago. 3. Ausencia de referencia al título ejecutivo en caso de actitud pasiva del deudor y sus consecuencias en el ejecutivo ulterior. IV. Consideraciones de detalle sobre algunos aspectos expresamente regulados. 1. Competencia (art. 506 ACPC). 2. Ámbito de aplicación (art. 507 ACPC). 3. Petición inicial como verdadera demanda sucinta y postulación de las partes (arts. 508, 35 y 513 ACPC). 4. Admisión o no de la petición inicial (art. 509 ACPC). 5. El requerimiento de pago y su notificación (arts. 510 y 511 ACPC). 6. "Incomparecencia" del deudor e innecesariedad de demanda ejecutiva (art. 512 ACPC). 7. Oposición del deudor y procedimiento ulterior (arts. 513 y 514 ACPC). V. Epílogo a modo conclusivo.

\section{CONSIDERACIONES PReliminares}

Poco antes a la elaboración y posterior publicación de este trabajo, en acto celebrado el 19 de diciembre de $2006^{1}$, se ha hecho entrega al Ministerio de Justicia chileno el Anteproyecto de Código Procesal Civil (en adelante ACPC), elaborado por un importante grupo de prestigiosos académicos, fundamentalmente pertenecientes a la Facultad de Derecho de la Universidad de Chile así como por diversos abogados, jueces y otros profesionales jurídicos pertenecientes al llamado Foro Procesal Civil.

En la presentación que inaugura el texto del Anteproyecto se reconoce la labor del trabajo de las muchas personas que han participado en su redacción, si bien literalmente reconoce estar "seguro que las imperfecciones y omisiones de los redactores del anteproyecto serán salvadas posteriormente, dado que no exista obra perfecta que salga de la mano del ser bumano o comisión alguna". Enlazando con esta idea, el presente trabajo pretende aportar algo de la experiencia española en un intento de contribuir en que efectivamente sean salvadas algunas de las que en mi opinión son imperfecciones u omisiones en el ACPC, centrándome ahora en las previsiones relativas al procedimiento monitorio contenidas en los arts. 506 a 514 del mismo.

Véase una referencia a este acto en bttp://www:minjusticia.cl/Comunicados/2006/DICIEMBRE/20_dicbre_2006,htm. 
La Ley 1/2000 de Enjuiciamiento Civil española (en adelante LEC), es buen ejemplo de gestación legislativa en la que se mejoró sustancialmente su texto inicial. La LEC fue publicada en el Boletín Oficial del Estado núm. 7 de 8 de enero de 2000, entró en vigor al año de su publicación y representó la culminación de un periodo previo suficientemente extenso, al menos de tres años, en el que se celebraron diversos foros con intensos debates doctrinales y profesionales ${ }^{2}$, en algunas ocasiones extremadamente críticos y, a esta distancia, quizá a veces expresados incluso con desproporcionada vehemencia doctrinal. En cualquier caso, todas estas aportaciones como mínimo llamaron la atención sobre la mayor parte de los puntos mejorables, y de hecho sin duda enriquecieron en mayor o menor medida su redacción, hasta el punto de que el texto inicial del Borrador de Anteproyecto de LEC, pasando por el Anteproyecto y Proyecto de LEC, hasta el definitivo publicado en el BOE eventualmente guarden importantes distancias de forma y de fondo. Así y todo, la patente mejora del texto que pretendía ser definitivo no ha impedido que a fecha de hoy haya sufrido ya repetidas modificaciones de cierto calado. Entre otras, dadas por Ley $15 / 2005$ de 8 de julio, que introduce novedades en materia de separación y divorcio; o por Ley 23/2003, de 10 julio, de Garantías en la Venta de Bienes de Consumo, que no obstante su denominación aporta importantes modificaciones, sobre todo nuevas especialidades en el juicio de desahucio por falta de pago. Por cierto, en muchos aspectos para dar marcha atrás y acercar su regulación a la derogada contenida en la LEC de 1881.

En lo referente al procedimiento monitorio, puede apreciarse nítidamente la evolución que sufrió su regulación en los diferentes textos prelegislativos, como no podía ser de otro modo consecuencia de las dificultades de acomodo que implica toda "importación" legislativa ${ }^{3}$. En mi opinión, a pesar de todo, la labor de mejora se ha revelado insuficiente como evidencian las muchas y graves discrepancias doctrinales y jurisprudenciales que ha provocado una deficiente regulación por excesivamente

2 El primero, que me conste, las llamadas "Jornadas Nacionales sobre el Anteproyecto de Ley de Enjuiciamiento Civil", celebrado en la ciudad de Murcia del 7 al 10 de octubre de 1997 y organizado por la Escuela de Prácrica Jurídica de dicha ciudad. Al que siguieron otras importantes citas en ciudades como Barcelona, La Coruña, Tarragona, etc.

3 Nótese que no fue una verdadera novedad en la LEC, pues en España se contaba con una experiencia previa. La Ley 8/1999, de 6 de abril, de reforma de la Ley de Propiedad Horizontal había introducido un año antes a la LEC el procedimiento monitorio, aunque fuera exclusivamente para la reclamación de gastos de comunidad de propietarios (sobre el mismo, en su configuración actual, puede verse BONET NAVARRO, J., La reclamación judicial de los gastos de comunidad, Edisofer, Madrid, 2004). Sin perjuicio, de otro lado, de otros precedentes más o menos remotos en los llamados procedimientos de jura de cuentas de los arts. 8 y 12 LEC 1881 así como el apremio en negocios de comercio en los arts. 1544 a 1560 de la misma. 
parca e imperfecta, sobre todo, por aquello que omite en su malograda pretensión de resultar sencilla.

Salvando las distancias culturales y de tradición jurídica que sin duda han de ser debidamente atendidas por el legislador, estimo que la importancia práctica del procedimiento monitorio en cuanto a su previsible utilización y a los intereses económicos que se ven implicados, así como la suficiente experiencia española en su instrumentación, permiten que resulte de interés aportar algunas consideraciones a modo de granos de arena que contribuyan a mejorar este interesante procedimiento, máxime si consideramos que consecuencia de sus indudables ventajas frente al tradicional "juicio ejecutivo", puede ser un firme candidato para competir en la conquista del "mercado" de la reclamación del crédito en los ordenamientos iberoamericanos que todavía no cuentan un procedimiento de estas características ${ }^{4}$.

\section{CONCEPCIÓN Y NATURALEZA JURÍdiCA DEL PROCEDIMIENTO MONITORIO EN EL ACPC}

\section{La indefinición en el texto del ACPC}

Las palabras que le dedica la presentación del ACPC no nos da pista alguna sobre la concepción y naturaleza jurídica de la que parte o ha querido dotar el legislador al procedimiento monitorio ${ }^{5}$. Se limita a poner de manifiesto que se incorpora este: "como procedimiento nuevo a nuestro sistema procesal civil, puesto que su aplicación en el derecho comparado nos han convencido de su utilidad práctica". Así y todo si se trata de una mera "incorporación" como se afirma, esta solamente se habrá podido producir respetando la concepción y naturaleza jurídica que sobre el procedimiento monitorio existen ya en el "derecho comparado".

El ACPC habla siempre de "procedimiento" monitorio, de modo que alude a los aspectos meramente formales o externos de la actividad procesal, a los de mera tramitación ${ }^{6}$. Esta denominación, en realidad correcta, deja positivamente subsistente la duda de si se está regulando un verdadero proceso, alguna especie de jurisdicción voluntaria o a lo

En la actualidad cuentan con procedimiento monitorio Brasil, Uruguay y Perú.

Véanse diversas posibilidades de configuración en PÉREZ RAGONE, A. J., "En torno al procedimiento monitorio desde el Derecho Procesal comparado europeo: caracterización, elementos esenciales y accidentales", en Revista de Derecho Universidad Austral de Cbile, Vol. XIX, núm. 1, julio 2006, págs. 205-35, http://www.scielo.cl/scielo.php? script $=s c i$ arttext $\mathcal{E}$ pid $=S 0718-09502006000100009 \mathcal{E} \ln g=e s \mathcal{E} n r m=i s o \mathcal{E} t \operatorname{lng}=e s \$ n 42$

6 Para una distinción entre proceso y procedimiento, puede consultarse ORTELLS RAMOS, M., Derecho Procesal. Introdicción (con JuAn y CAMARA), Edisofer, Madrid, pp. 23-6. 
sumo actos preparatorios del verdadero proceso de ejecución que le podrá seguir.

Podría objetarse que estas consideraciones son divagaciones meramente dogmáticas carentes de una verdadera utilidad. En mi opinión, nada más lejos de la realidad. Aparte de que una idea clara sobre la concepción y naturaleza jurídica de este mecanismo de tutela judicial del crédito sin duda nos permitirá entenderlo mejor y, en el momento de su aplicación, integrarlo adecuadamente en sus eventuales lagunas, conocer qué es, o qué se pretende con el mismo, favorece que se elabore una regulación que colme las expectativas plenamente y con mayor precisión técnica.

En el presente texto del ACPC llama la atención, aunque sea con intensidad variable, entre otras cosas, lo siguiente:

- Se dice que servirá "para reclamar" el pago de deudas (art. 507).

- El escrito de iniciación no se denomina "demanda" sino "petición inicial" (arts. 508, 509)7, ni al acreedor "demandante" sino "peticionario" (art. 510.2).

- Se habla de que la petición inicial "será desestimada" por los motivos del art. 509.1 y 2, que son claramente formales y no de fondo.

- Si se cumplen los requisitos, el juez "despachará" requerimiento (art. 510).

- Si no hay pago ni oposición, "despachará de oficio" mandamiento de ejecución y embargo (art. 512).

- Se afirma que el monitorio finalizará tanto si se abre la ejecución (art. 512) como al formularse oposición (art. 514).

- Y, sobre todo, no se prevé que el monitorio tenga efecto alguno de cosa juzgada cuando el deudor no paga ni formula oposición. Es más, el art. 509 in fine parece excluirlo ${ }^{8}$

Un procedimiento con estas características, sobre todo no dotado de cosa juzgada y reducido al mero requerimiento pues finaliza en todo caso si hay pago, oposición o "incomparecencia" (o mera comparecencia sin oposición ni pago) del deudor, pone en tela de juicio su conceptuación

Sin embargo, en otros momentos sí se uriliza la expresión "demanda monicoria" (art. 35 a) $\mathrm{ACPC}$ ).

8 Digo que parece excluirla porque no obstante el equívoco término "desestimar", ningún efecto de cosa juzgada habría de corresponder a dicha "desestimación", pues nada ha sido juzgado en ese momento ni en realidad desestimado, al menos con contradicción, sino que sencillamente se ha rechazado la petición por razones estrictamente formales. Y por si había alguna duda sobre este aspecto, en caso de que se cumplan los requisitos formales de los arts. 506 a 508 ACPC, el art. 510.1 del mismo impone que el juez incorpore en el requerimiento de pago "la advertencia de que el Tribunal no ha examinado la justificación de la deuda antes de despachar el requerimiento de pago". 
como verdadero proceso y, lo que es más grave, reduce a mínimos su aprovechamiento operativo.

Ciertamente, se ha previsto como un procedimiento judicial, pero ya no resulta tan obvio entender que el juez actúa con verdaderas funciones jurisdiccionales. Si el procedimiento no se inicia con demanda, finaliza ocurra lo que ocurra tras el requerimiento y no tiene en ningún caso efecto de cosa juzgada, esto es, consiste básicamente en un requerimiento para que pague el deudor, la intervención judicial, al menos ejerciendo potestad jurisdiccional, no resulta imprescindible. A lo sumo el juez actuaría con función de mera garantía de los derechos, en este caso, de que el requerimiento se practique con garantías y más en concreto, como dispone el art. 511 ACPD, personalmente entregándole "copia íntegra de la resolución y de la solicitud en que haya recaído". Pero tal actividad estrictamente no pertenece al ámbito exclusivo de la función jurisdiccional, más bien es de naturaleza administrativa. Parece claro que requerir con garantías no exige la intervención judicial, ni mucho menos ejerciendo potestad jurisdiccional, pues perfectamente podría ofrecer garantías equivalentes la actuación de otra autoridad o persona habilitada, como de hecho ocurre habitualmente en procedimientos como los administrativos sancionadores y otros. Ahora bien, hay indicios en el ACPC que permiten inclinarnos por entender que la voluntad es la de atribuir a la actuación judicial el ejercicio de potestad jurisdiccional y por tanto alzando el procedimiento monitorio a la categoría de verdadero proceso. En la presentación del ACPC, se afirma que en su texto "no se consideran los denominados asuntos judiciales no contenciosos, los que atendida su naturaleza juridica administrativa deberá ser tratada en una ley especial". De otra parte, a la "incomparecencia" del deudor se atribuyen tan graves consecuencias como que se dicte mandamiento de ejecución y embargo (art. 512 ACPC). Por último, en la propia literatura utilizada en el texto de la regulación se habla de "proceso monitorio" y no solamente de procedimiento, así ocurre por ejemplo en los arts. 506.I, 509 in fine y 514.I ACPC. Por estas razones podemos escorarnos a entender que no se quiere regular un mero procedimiento de la llamada "jurisdicción voluntaria" en que el juez solamente actúa en garantía de derechos, sino un verdadero proceso, por tanto, judicial y jurisdiccional.

Más dificultades encuentro para excluir su posible naturaleza como conjunto de actos preparatorios del juicio ejecutivo posterior. Nada obsta para que se reduzca a mera actividad preparatoria si en definitiva no se trata más que de una petición de requerimiento de pago que, si se cumplen unos determinados presupuestos formales, supondrá una orden al deudor para que en el plazo de quince días pague al "peticionario" o comunique su oposición, con la advertencia de que en caso contrario se despachará de oficio mandamiento de ejecución y embargo, y se iniciará así el juicio ejecutivo por obligación dineraria en su contra. Y en simple 
requerimiento se queda todo porque si el deudor paga lógicamente no procede realizar nuevo acto más que el de finalización; si hay oposición, lo mismo y ya se discutirá en su caso; y, por último, si hay incomparecencia, igualmente finalizará transformándose de oficio, por tanto sin necesidad de demanda ejecutiva alguna por el acreedor, en juicio ejecutivo. La sucesión de actos que conforman el procedimiento monitorio se preordenan a la formación de un título ejecutivo que sería por último el fundamento del juicio ejecutivo ulterior. El problema técnico ahora es que el título ejecutivo al que se preordenaría esta actividad preprocesal no se menciona en ningún momento. Es más, ni siquiera se exige como requisito para el inicio del procedimiento que la "deuda" tenga un mínimo soporte documental (art. 507 ACPC).

Puesto que por definición y por derecho positivo (incluido el art. 395 ACPC) el título ejecutivo se caracteriza por contar con soporte documental, y porque el mandamiento de ejecución y embargo es posterior y pone fin al monitorio (art. 512 ACPC), tal y como está previsto en el ACPC difícilmente podrá ser calificado como estrictamente ejecutivo.

Que se caracterice por sus elementos declarativos resulta también discutible. En primer lugar y aunque tenga una importancia meramente lingüística, es así porque no se inicia con demanda, y porque no está dotado de eficacia de cosa juzgada, lo que tampoco sería totalmente relevante pues algunos de los procesos declarativos sumarios están privados de efecto de cosa juzgada (art. 394.II a IV ACPC). Pero si lo anterior es meramente indiciario, si se une a que el monitorio no soporta la contradicción, hasta el punto que la oposición en tiempo y forma tendrá como efecto su finalización (art. 514.I ACPC), hacen que la calificación como proceso declarativo se dificulte sobremanera. Solamente podría vislumbrarse algún carácter declarativo cuando, al no producirse oposición ni pago, permite "crear" un "título ejecutivo" fundamento del juicio ejecutivo ulterior, siendo que en principio la deuda no tiene por qué tener necesariamente carácter documental (art. 507 ACPC).

$\mathrm{Y}$ por último, sostener que el procedimiento monitorio, incluido el regulado en el ACPC, tiene naturaleza jurídica específica, llámese monitoria o como se quiera, y por tanto atípica respecto del resto de procesos, me parece un modo como cualquier otro de poner de manifiesto la incapacidad para encuadrar debidamente la naturaleza de un procedimiento especial, con sus particularidades y características propias. Creo que los procesos son bien de declaración o bien de ejecución, y a lo sumo, cautelares, en modo alguno existen categorías autónomas a las anteriores. Otra cosa es que su encuadre definitivo pueda resultar dudoso por la concreta indefinición del legislador y por la propia naturaleza especial del procedimiento monitorio, en el que muchas veces se estructura con elementos declarativos, ejecutivos y hasta cautelares. Que el monitorio pueda encuadrarse en alguna de estas categorías no dependerá de una 
necesidad derivada de su, por otro lado, discutible esencia, sino sencillamente de la voluntad política y técnica del legislador en su configuración.

Sin perjuicio de que un procedimiento monitorio ha de cumplir con unas características esenciales básicas que le permitan servir, en palabras de la Real Academia de la Lengua, "para avisar", su definitiva configuración corresponde sin duda a una opción legislativa. Dicha opción permitirá que el procedimiento pueda ser aprovechado en todas sus posibilidades, o bien que se convierta en unos actos con poca o nula utilidad práctica. Por ello es más que conveniente que el legislador parta de una idea clara sobre qué es y principalmente qué se pretende con el procedimiento monitorio, conocer para ello las posibilidades que ofrece y aprovechar las que se consideren adecuadas.

En mi opinión, tal y como se configura en la actualidad, el instrumento regulado en los arts. 506 a 514 ACPC no solamente refleja una poco clara definición conceptual, sino, lo que es más grave, se encuentra desaprovechado y, de no modificarse, abocado al mayor de los fracasos en cuanto a su utilidad práctica.

\section{Una forma de entender y aprovechar el proceso monitorio}

El monitorio se introduce en un ordenamiento jurídico, como se viene a reconocer en la presentación del ACPC, para aprovechar su "utilidad práctica”, y al tiempo porque mejora el mecanismo procesal preexistente en este caso para obtener el cobro del crédito.

En materia tan habitual y común como la reclamación del crédito en sede judicial, la experiencia y la estadística demuestran que, cuando se cumplan unas determinadas condiciones en la obligación (principalmente, una cantidad líquida, vencida, exigible y con soporte documental), la actitud que suele adoptar el demandado es la resistencia pasiva, no hacer nada; y en las pocas ocasiones que adopta una actitud activa formulando oposición, esta tiene escaso fundamento. Todo ello se traduce en elevadas cifras de estimación de este tipo de pretensiones con la condena del demandado, a costa de agotar los sucesivos plazos del procedimiento que dadas las circunstancias ha resultado innecesario.

Pues bien, el monitorio puede ser entendido como la respuesta más eficaz con que cuenta el legislador frente a la actitud pasiva que suele adoptar el deudor en estos casos. De ese modo, cuando adopte esta actitud voluntariamente (de ahí la importancia de que el requerimiento sea personal) no se pierda "procesalmente" el tiempo, y directamente terminen las actividades procesales distintas a las propias del proceso de ejecución. En cambio, a diferencia de lo que ocurre con otros mecanismos de tutela del crédito, como sería el juicio ejecutivo, al deudor que adopta un actitud activa formulando oposición no se le grava con incidentes 
constreñidos en cuanto a sus trámites y/o con posibilidades materialmente limitadas de discusión, sino que se le permite debatir sobre los motivos por los que no ha de pagar sin restricciones en un proceso común u ordinario, tal y como se contempla en el art. 514.III ACPC, el que corresponda en razón de la cuantía.

Así, el procedimiento monitorio se constituye por un núcleo esencial: el requerimiento personal de pago si es admitida la petición para que este se realice. Y se articula y complementa por un "juego" de actos eventuales principales: por los trámites para sustanciar y decidir la oposición, si esta se ha formulado; y, en caso contrario, por los trámites para que se cumpla forzosamente la obligación cuando sea necesario por no haber pagado. Todos estos actos de un modo u otro vinculados o relacionados.

Vista en toda su dimensión, la operatividad y utilidad del monitorio consiste en una muy especial tutela judicial del crédito, algo más que una mera reclamación dineraria y garantizada judicialmente. Igualmente, esta misma configuración excluye en mi opinión que quepa ser considerado como proceso de ejecución, al menos porque la mera oposición pondría final a esa discutible ejecución, transformándolo ("transformar" no es exactamente lo mismo que "finalizar") en su caso en declarativo, y porque el mandamiento de ejecución y embargo que inicia la ejecución es precisamente el que pone fin al monitorio.

Que este procedimiento monitorio termine por configurarse en el definitivo Código Procesal Civil como una sucesión de actos más o menos organizados procedimentalmente y preparatorios de la posterior ejecución, o como un verdadero proceso declarativo especial, forma parte de la opción "técnico-política" del legislador. Pero, en mi opinión, el modo más consecuente con una perspectiva omnicomprensiva de la tutela que se ofrece al crédito con la llamada "técnica monitoria", y, sobre todo, la forma de aprovechar todas las posibilidades que permite el monitorio, pasa por considerarlo y regularlo como algo más, mucho más, que unos meros actos preparatorios de una eventual ejecución, sino como un verdadero proceso de declaración, muy especial ciertamente, e integrado por un requerimiento y con unos actos que, por muy eventuales que se consideren, cuando se produzcan tengan toda la eficacia.

Parece que resulta conveniente, cuando no necesario, contar con un proceso monitorio que resulte eficaz y no se vea fácilmente frustrado solo por la voluntad del demandado. Lamentablemente esto es lo que permitiría el ACPC. Tal y como se configura hoy por hoy, el procedimiento monitorio está abocado al más estrepitoso de los fracasos, consecuencia de los desorbitados efectos que se atribuyen en el art. 513 ACPC a la oposición señalando "las razones por las cuales no debe en todo o en partes la deuda u otros motivos por los cuales no debe en definitiva despacharse ejecución en su contra". En efecto, si esta oposición tiene como virtualidad que se ponga fin al monitorio (art. 514.I ACPC), sin consecuencia 
alguna para las partes y en particular sin que las razones en que se funde la oposición sean vinculantes "para en el eventual proceso declarativo ordinario que se lleve a cabo posteriormente" (art. 513. IV ACPC), es claro que la viabilidad y eficacia del procedimiento monitorio va a depender de la sola voluntad del deudor que decida ponerle fin presentado un mero escrito sin mayores exigencias más que tenga la apariencia de razones por las que no debe pagar. Y es que sin previsión de sanción, consecuencia negativa alguna ni particular exigencia, podrá el deudor formular la oposición que considere oportuno en la que esgrima "razones" diversas por las que no debe. Lo grave es que se atribuye consecuencia finalizadora del monitorio desvinculada del ulterior proceso a un escrito en el que se aporten tales "razones" sin que haya circunstancias que impongan o favorezcan que las mismas tengan alguna correspondencia con la realidad, fundamento o acreditación. El deudor queda libre para decir sin control ni consecuencia negativa lo que mejor le venga en gana sin limitación alguna. Y lo que diga hará que termine el monitorio.

Solamente hay un aparente atisbo de consecuencia negativa para el deudor que formula oposición, cuando en el art. 510.3 se habla de que "de no presentarse oposición o de rechazarse esta por el Tribunal, se despachará de oficio...". Parece así que la oposición podrá ser "rechazada", aunque no sea por incumplir con una acreditación, fundamento o correspondencia con la realidad de las razones afirmadas. Más bien este "rechazo", término equivalente a no admisión y mucho más correcto que el de "desestimación" a estos efectos como luego indicaré, implica que el juez atienda a cuestiones estrictamente formales, como lo corrobora el que el art. 512 ACPC hable de que si la oposición "fuere rechazada por el Tribunal por no cumplir con algún requisito de forma o por presentarse fuera de plazo, este dictará de oficio mandamiento...". De ese modo, la única exigencia que se impone al deudor al formular oposición es cumplir con unos requisitos formales y temporales, a partir de ahí, puede decir lo que mejor se le ocurra, puesto que, diga lo que diga con apariencia de razón, pondrá fin al monitorio sin que le acarree consecuencia adversa alguna.

En mi opinión, para aprovechar debidamente los beneficios que ofrece el procedimiento monitorio, este ha de cumplir con dos características generales por el momento ausentes en el texto del ACPC:

\section{A) Eficacia de cosa juzgada cuando el proceso finalice por falta de pago u oposición}

Sin perjuicio de la utilidad que pueden ofrecer los procesos sumarios excluidos algunos de ellos en la ACPC del efecto de cosa juzgada (art. 394 ACPC), y al margen de otras consideraciones dogmáticas, la mejor forma de proteger el crédito, otorgar seguridad jurídica a la posición del acreedor y dotar de mayor eficacia al monitorio es cerrando las posibili- 
dades de ulteriores debates sobre la existencia y subsistencia de la deuda entre las partes. Además de los inconvenientes prácticos que podría tener una decisión que eventualmente impusiera la restitutio in integrum, el deudor ha tenido ya oportunidad para ejercer en el ámbito del procedimiento monitorio el derecho de defensa sin restricciones formales ni materiales pues con la misma en definitiva se cierra el monitorio y quedan abiertas las puertas del correspondiente procedimiento ordinario o sumario adecuado por la cuantía.

\section{B) Vinculación e intima conexión de la oposición del deudor con el eventual proceso ulterior para sustanciarla}

El éxito de la eficacia práctica de este procedimiento, sobre todo cuando se trata de cuantías elevadas, en mi opinión radica en que al deudor no le salga "gratis" la oposición. Tal y como se configura actualmente el ACPC, con esta "finalizará el proceso monitorio", sin perjuicio de que posteriormente quede abierto el declarativo que corresponda por la cuantía, y "las razones esgrimidas por el deudor para oponerse al requerimiento de pago no serán vinculantes para en el eventual proceso declarativo ordinario que se lleve a cabo posteriormente" (arts. 514.I y 513.IV ACPC, respectivamente). Como ya he indicado antes, solamente con cumplir ciertos requisitos formales y temporales, el deudor podrá finalizar el monitorio y frustrar todos los esfuerzos procesales realizados, sin que lo indicado en dicho escrito de oposición tenga consecuencia negativa alguna para el deudor a pesar de la posible falta de fundamento o de correspondencia con la realidad. Es de prever, por tanto, que si no se adoptan cambios profundos en este aspecto, todo procedimiento monitorio terminará con la oposición del deudor -y luego ya veremos qué pasa en el declarativo que corresponda por la cuantía-, y por ese camino, los acreedores preferirán no perder el tiempo necesario para su tramitación. Puedo vaticinar que el juego de los citados arts. 513 y 514 ACPC conducirán a medio y largo plazo en la absoluta inutilidad de este procedimiento.

Si observamos en toda su dimensión la tutela judicial del crédito que se ofrece con la llamada técnica monitoria, y el juego de eventualidades que implica, fácilmente ha de ponerse en tela de juicio que el proceso adecuado por la cuantía para conocer de la pretensión en que se funde el crédito tenga una real autonomía con el procedimiento monitorio (por la identidad esencial en su elementos subjetivos y objetivos) ${ }^{9}$. En realidad,

Sobre esta cuestión en el derecho español, véase BONET NAVARro, J., "La relativa autonomía del 'Juicio que corresponda' tras la oposición en los procedimientos monitorios", en Problemas actuales del proceso iberoamericano. XX Jornadas iberoamericanas de Derecho Procesal, I, Actas, CEDMA, Málaga, 2006, pp. 373-86. 
la función de este proceso no habría de ser más que la de conocer sobre si ha de estimarse o no la oposición del deudor y, por tanto, poner fin al conflicto de modo definitivo y con eficacia de cosa juzgada entre acreedor y deudor.

El modo con que se configure esta vinculación ya no tiene una relevancia fundamental. La técnica utilizada en este punto en el Derecho español no me parece la más adecuada, sobre todo por su inexplicable diversidad en función de la cuantía del procedimiento ${ }^{10}$. Este régimen dispar, además de los inconvenientes que derivan de la propia disparidad que instaura, supone al menos dos cosas negativas: que en el caso del juicio ordinario, dudosamente el deudor queda vinculado a los motivos de oposición formulados; y que, como consecuencia de lo anterior, al final los acreedores no estén optando por iniciar monitorios cuando la cuantía supere tres mil euros, puesto que, en tal caso, como resulta "gratis" formular oposición, el tiempo necesario para la tramitación del monitorio hasta la oposición es tiempo perdido; y si esto no fuera suficiente, al acreedor se impone en tales casos la carga de interponer la demanda so pena de pechar con las costas. Nótese como en el derecho español el nivel de vinculación con la oposición en el juicio ordinario ulterior es en cierto modo algo superior al previsto en el ACPC. Es de prever por tanto que con la situación en la actual redacción del ACPC, deriven consecuencias todavía más traumáticas para la pervivencia y utilidad práctica de este procedimiento en el caso chileno.

La vinculación de la oposición con el ulterior proceso adecuado por la cuantía para sustanciar la oposición sirve para evitar que las oposiciones puedan formularse "alegremente" y sin consecuencias. El proceso monitorio en tal caso terminará solamente cuando realmente existan motivos fundados para no pagar. Y será así sobre todo porque de lo contrario el deudor tendrá consecuencias negativas graves, entre otras, que en el declarativo ulterior no pueda ampliar esas defensas, o que pueda ser condenado en costas si no se estima aunque sea parcialmente la oposición. Además, el enlace del procedimiento monitorio con el ulterior declarativo sirve para ofrecer una tutela judicial del crédito coherente con el derecho de contradicción, pues en caso contrario la finalización del monitorio, tal y como se prevé en el art. 514.I ACPC, se producirá sin darle oportunidad al acreedor de formular alegación alguna al respecto.

\footnotetext{
10) Según el art. 818 LEC: "cuando la cuantía de la pretensión no excediera de la propia del juicio verbal, el tribunal procederá de inmediato a convocar la vista. Cuando el importe de la reclamación exceda de dicha cantidad, si el peticionario no interpusiera la demanda correspondiente dentro del plazo de un mes desde el traslado del escrito de oposición, se sobreseerán las actuaciones y se condenará en costas al acreedor. Si presentare la demanda, se dará traslado de ella al demandado conforme a lo previsto en los artículos 404 y siguientes de la presente Ley".
} 
Partiendo de lo anterior, la vinculación de la oposición con el ulterior proceso se revela como muy conveniente y hasta necesaria, se mire por donde se mire. El modo en que se instrumente es una cuestión menos relevante, caben posibilidades varias y corresponde a la opción legislativa. Una forma de instrumentación puede ser simplemente previendo que los motivos de oposición configuren exclusivamente y delimiten el objeto del ulterior proceso plenario para conocer de la existencia o subsistencia de la deuda; otro modo, con la vinculación todavía más acentuada y que pondría de manifiesto mejor el "juego" de eventualidades en que consiste el monitorio, sería que la oposición constituyera la demanda que de un lado pone fin al monitorio y de otro abre el juicio que corresponda por la cuantía para sustanciar la oposición, con remisión a tal efecto a las normas correspondientes del juicio ordinario o "sumario" que correspondiera por la cuantía.

En definitiva, la garantía de que la seriedad y eficacia del proceso monitorio quede garantizada hace urgente eliminar la previsión contenida en el actual art. 513.IV, estableciendo el mecanismo correspondiente para que se produzca la adecuada vinculación de las razones contenidas en la oposición del deudor para no pagar que "finaliza" -o más bien "transforma" el monitorio- con el objeto del proceso que corresponda para sustanciar esta oposición. Solamente de ese modo contaremos con un sistema en que la oposición quede reservada a los supuestos en que realmente existan razones fundadas para no pagar, pues de no ser fundadas, el deudor verá desestimada su pretensión de oposición con todo lo que ello implica desfavorable a sus intereses patrimoniales y, de ese modo, constituyéndose en incentivo para la seriedad de la oposición.

\section{CONSIDERACIONES SOBRE ALGUNOS ASPECTOS HUÉRFANOS DE ATENCIÓN EXPRESA}

Posiblemente el mayor defecto de técnica legislativa que puede achacarse a la regulación del proceso monitorio en la LEC española así como también en el texto del ACPC es que pretendiendo ser extremadamente sencilla, por parca, omiten hacer referencia a algunas cuestiones importantes, quizá considerándolas excesivamente obvias como para ocuparse de ellas. Al margen de omisiones puntuales ya indicadas como la atribución de cosa juzgada y otras sobre diversas cuestiones de detalle a los que luego me referiré, exactamente igual a lo que ocurre con la LEC española, se omite en el texto del ACPC una referencia clara al título ejecutivo fundamento del ulterior juicio ejecutivo así como al modo en que podrá articularse la declinatoria en el seno del procedimiento monitorio. 


\section{LA ALEGACIÓN DE LA "FALTA DE JURISDICCIÓN, INCOMPETENCIA DEL TRIBUNAL O EXISTENCIA DE COMPROMISO”}

\section{A) La declinatoria en el seno del procedimiento monitorio y en rela- ción con el procedimiento posterior a la oposición}

Conforme el art. 139 ACPC, "las partes deberán promover cuestiones de competencia solamente por vía declinatoria"; y el art. 140 del mismo, tras disponer que se propondrá ante el "tribunal" que está conociendo del asunto y a quien se considera incompetente, indica que su tramitación se sujetará a las reglas establecidas para los incidentes. A su vez, el art. 126.I del repetido ACPC, deja claro que "el incidente que se funde en un hecho anterior al juicio o coexistente con su principio, deberá promoverse antes de hacer cualquiera gestión principal en el pleito. Si lo promueve después, será rechazado de plano por el tribunal".

Esta regulación general encuentra difícil acomodo entre los especiales trámites del proceso monitorio. Lo que se evidencia cuando el art. 141 ACPC prevé que no suspenderá el curso de la causa principal, limitando esta suspensión al juicio ordinario pues se refiere a que podrá "el tribunal que esté conociendo de ella librar todas las providencias para la realización de las audiencias preliminar y de juicio como las que revistan el carácter de urgentes, como lo son las medidas cautelares".

La gran pregunta es, tal y como está configurada: ¿cabe formular declinatoria en el ámbito del proceso monitorio? Por los términos expeditivos del citado art. 126.I parece que sí. Es más, habrá de formularse en el plazo de quince días otorgados en el requerimiento y antes de la oposición ("antes de hacer cualquier gestión principal en el pleito") pues en caso contrario, si se promueve después, la declinatoria será rechazada de plano.

Si entendemos que la declinatoria es una especial y previa defensa de carácter procesal a favor en este caso del deudor ${ }^{11}$, en la que procede denunciar la falta de jurisdicción o de competencia en todas sus modalidades ${ }^{12}$, como mínimo este incidente o bien ha de tener efectos suspensivos del plazo para formular oposición en contradicción con lo dispuesto

11 Por ejemplo, Ortells Ramos, M., Derecho Procesal Civil (con Mascarell, Cámara, Juan, Bonet, Cucarella, Bellido y Martín), Thomson-Aranzadi, 6a ed., Cizur Menor, 2005 , p. 231 , califica a la declinatoria como "un medio específico de defensa procesal".

12 Lo planteo en términos hipotéticos porque en el texto del ACPC parece que se mantiene vigente de algún modo la vieja polémica sobre la naturaleza jurídica de la declinatoria, puesto que si bien en los arts. 139 y 140 ACPC sujetan su tramitación a los trámites de los incidentes, el art. 258.1) ACPC prevé para el juicio ordinario que "el demandado en la contestación de la demanda puede plantear como excepciones previas: 1) La falta de jurisdicción, la incompetencia del tribunal o la existencia de compromiso...". 
en general por el art. 141 ACPC, o de lo contrario esta habrá de formularse en plazo aunque sea preventivamente. $\mathrm{Y}$ si esta se formula, los efectos son rotundos en el art. 514: "finalizará el proceso monitorio".

Este problema de encaje se magnifica todavía más si entendemos, como parece pretender el ACPC, que el "procedimiento" posterior a la oposición es autónomo al monitorio que ya ha finalizado como expresa y rotundamente dispone el citado art. 514.I ACPC. Ahora bien, en el punto III del mismo precepto se atribuye competencia funcional para conocer de este pretendidamente autónomo proceso cuando indica que "cualquiera de las partes podrá iniciar ante el mismo Tribunal ante el cual se sustanció el monitorio el procedimiento ordinario que corresponda en razón de la cuantía de la oposición, rigiéndose dicho proceso en su totalidad por las normas contenidas en el Título I del Libro IV de este mismo Código". Salvo el posible pero improbable supuesto en que el deudor inste procedimiento para que se declare en definitiva como indebida la obligación de pago, la siguiente pregunta versará sobre la admisibilidad en este segundo procedimiento la declinatoria instada por el deudor.

En principio, si la oposición finaliza el monitorio y el procedimiento posterior a la oposición es autónomo, "rigiéndose dicho proceso en su totalidad por las normas del Título I del Libro IV de este mismo Código", parece que nada excluiría que pudiera formularse. Ahora bien, no ha de pasar por alto que la competencia que se atribuye para conocer de este procedimiento es funcional (se dice en el art. 514.III ACPC que "cualquiera de las partes podrá iniciar ante el mismo Tribunal ante el cual se sustanció el monitorio"). Esto implica que en el momento de formular oposición en el procedimiento monitorio se conocía ya el órgano ulteriormente competente para el procedimiento posterior a la oposición, de modo que, si en el inicial cabía declinatoria como se apuntaba, el deudor contará con dos posibilidades para defenderse frente a la misma indebida atribución competencial: La primera, en el monitorio; y, en cuanto la competencia del monitorio determina la funcional en el ordinario ulterior, también en el seno de este último. Lo bien cierto es que si hay incompetencia, ya la había desde el primer momento en el monitorio, de modo que si en el mismo no formula declinatoria, parece que atendido el art. 126.I ACPC, habría de rechazarse de plano por el tribunal al haberse promovido tras hacer una gestión tan principal para el deudor como sería la formulación de la oposición.

Y similares consideraciones cabría hacer en el caso de que se dicte mandamiento de ejecución y embargo por no pagar ni formular oposición admisible, puesto que según el art. 512 la competencia para la ejecución posterior será igualmente funcional a favor del mismo órgano que ha conocido del monitorio; y el art. 408 ACPC autoriza a que el ejecutado pueda "también oponerse a la ejecución alegando en el mismo escrito y 
en forma subsidiaria a la oposición uno o más de los siguientes motivos formales: 1. "Incompetencia del tribunal...".

Como puede observarse, estas disfuncionalidades en la articulación de la declinatoria ponen en evidencia que el monitorio y el ulterior proceso tras la oposición no es tan autónomo como se pretende; y sobre todo, se producen, como ocurre en la LEC española, por la carencia de una previsión específica en el ACPC que adecue su tramitación a los especiales trámites y caracteres de la llamada técnica monitoria.

\section{B) La "falta de jurisdicción, incompetencia del tribunal o existencia de compromiso" como excepción de carácter procesal}

Dados los términos del art. 513.II ACPC, referido literalmente a que "deberá el deudor requerido señalar las razones por las cuales no debe en todo o en partes la deuda u otros motivos por los cuales no debe en definitiva despacharse ejecución en su contra", no resultará dudoso que podrá fundar sus defensas basándose en cuestiones estrictamente procesales pues se tratará en definitiva de motivos por los cuales no ha de despacharse ejecución.

Sin embargo, las dudas sobre la admisibilidad subsisten en relación con la llamada "falta de jurisdicción, incompetencia del tribunal o existencia de compromiso". Parece claro que nada excluye su denuncia a través de la declinatoria pero, a diferencia de lo que ocurre en otros supuestos como el art. 390.III $\mathrm{ACPC}^{13}$, tampoco hay previsión que impida la admisibilidad de su alegación como excepción, tal y como se autoriza en el mismo ACPC para otros procedimientos como el juicio ordinario (art. 258.1) o el proceso de ejecución (art. 408.1\%).

Tal y como está configurado el procedimiento monitorio, y salvo que llegáramos a la discutible conclusión de que la regulación del procedimiento sumario es de aplicación general, y por tanto también el art. 390.III ACPC, resulta a todas luces conveniente que se aclarase el modo en que habrá de articularse en el seno del procedimiento monitorio la defensa del deudor basada en la falta de jurisdicción o de competencia en todas sus modalidades, sea mediante declinatoria o sea como excepción procesal que integrase la oposición.

13 Dice este precepto al regular la audiencia en el procedimiento sumario que "el demandado no podrá impugnar en este momento la falta de jurisdicción o de competencia del tribunal, que hubo de proponer en forma de declinatoria según lo dispuesto en el artículo 258 de la presente Ley, sin perjuicio de lo previsto sobre apreciación de oficio por el tribunal de su falta de jurisdicción o de competencia". 


\section{Ausencia de referencia expresa al pago}

No obstante ser el monitorio un instrumento preordenado principalmente a obtener el pago por el deudor, no se contiene una previsión específica al modo en que este habrá de instrumentarse en el seno del procedimiento monitorio. No se sabe, por tanto, si en el ACPC se considera innecesario regular el pago por tener naturaleza de derecho privado como medio de satisfacción de las obligaciones; si ha sido un olvido del redactor; o si, por el contrario, pretende remitir a la regulación contenida en el propio texto del ACPC sobre el pago ( 424 ACPC) $)^{14}$.

En mi opinión, cualquiera de las posibilidades son aceptables desde un punto de vista de política legislativa. En derecho español se opta en principio por regular la forma de pago diversa en el ámbito del procedimiento monitorio (art. 817 LEC) y en el proceso de ejecución (art. 583 LEC); si bien en otros procesos en que se instrumenta igualmente la técnica monitoria, como es el juicio cambiario, se opta por remitir al art. 583 LEC, que disciplina el pago en el proceso de ejecución (art. 822 LEC).

Lo que plantea innecesarias dudas es el silencio que guarda la redacción del ACCP sobre el modo y las consecuencias que tendrá el pago sobre el fin del monitorio y sobre las costas. Si como hemos visto difícilmente puede tildarse el monitorio como un proceso de ejecución, resulta forzada la aplicación del art. 424 ACPC como regla general, en cuanto este regula el pago en el ámbito del proceso de ejecución y por ello se ubica sistemáticamente en el Capítulo II (ejecución dineraria), Título II (del juicio ejecutivo) del Libro IV. De otro lado, quizá sea un olvido o una consciente omisión por tratarse el pago de una institución de carácter material, pero en cualquiera de los casos anteriores convendría hacer una referencia exacta a cuál es la voluntad del legislador en este punto para despejar innecesarias dudas: sea señalándose que el pago podrá verificarse y acreditarse de modo más o menos aformal, regulando específicamente el pago en el ámbito del monitorio, o con remisión expresa al art. $424 \mathrm{ACPC}$.

14 El art. 424 ACPC es copia exacta al art. 583 LEC, salvo en que no numera los párrafos. Disponen ambos que "si el ejecutado pagase en el acto del requerimiento o antes del despacho de la ejecución, se pondrá la suma de dinero correspondiente a disposición del ejecutante, se entregará al ejecutado justificante del pago realizado y, en su caso, se dará por terminada la ejecución. Aunque pague el deudor en el acto del requerimiento, serán de su cargo todas las costas causadas, salvo que justifique que, por causa que no le sea impurable, no pudo efectuar el pago antes de que el acreedor promoviera la ejecución". 


\section{Ausencia de referencia al título ejecutivo en caso de actitud} pasiva del deudor y sus consecuencias en el ejecutivo ulterior

Ya hemos visto que es característica básica del monitorio "castigar" la actitud pasiva del deudor evitando perder procesalmente el tiempo con más trámites y pasando directamente a la ejecución. En tal sentido, el art. 512 ACPC prevé que "si el deudor requerido no presentare oposición o si esta fuere rechazada por el Tribunal por no cumplir con algún requisito de forma o por presentarse fuera de plazo, este dictará de oficio mandamiento de ejecución y embargo por la cantidad adeudada más los intereses, finalizando así el monitorio e iniciándose un juicio ejecutivo que se regirá por las normas contenidas en el Párrafo 2 del Título II del Libro IV de este Código".

En relación con su redacción ha de notarse que en el Libro IV, sobre los procesos especiales, su título II se dedica al llamado "juicio ejecutivo". Y dentro del mismo, tenemos diversos capítulos, el $1^{\circ}$ sobre disposiciones generales; el $2^{\circ}$, de la ejecución dineraria, y este último a su vez, dividido en dos párrafos, el $1^{\circ}$ de disposiciones generales, y el $2^{\circ}$ sobre el embargo de bienes. Ciertamente no tengo claro si se trata de una errata y se quiere referir al Capítulo $2^{\circ}$ del citado Título y Libro; o solamente al párrafo $2^{\circ}$ del Capítulo $2^{\circ}$ de idénticos Título y Libro. Como no creo que quieran excluir el resto de párrafos del mismo capítulo (disposiciones generales, bienes inembargables, garantías de la traba o el embargo, administración judicial, disposiciones generales sobre realización, etc.), en principio parece que se trata de una errata y en lugar de párrafo $2^{\circ}$ habría de decir Capítulo $2^{\circ}$.

La anterior consideración sería de mero matiz si con la misma no pareciese excluirse la posibilidad de formular oposición en el ámbito del eventual juicio ejecutivo, pues esta se regula en los arts. 406 y ss., por tanto dentro del Capítulo $1^{\circ}$, del Título II del Libro IV del ACPC. A pesar de la expresa remisión al Párrafo-Capítulo $2^{\circ}$ que realiza el art. 512 ACPC, no parece que se quiera excluir la oposición en el ámbito del juicio ejecutivo (aunque sorprendentemente no se encuentra una referencia clara al principio de contradicción y al pleno ejercicio del derecho de defensa de las partes entre los principios básicos contenidos en el Título I, del Libro I, arts. 1 a 19 ACPC). En cualquier caso, resulta más que conveniente que esta cuestión quedara clara modificando la redacción del citado art. 512.

Partiendo de la creencia de que, a pesar de lo indicado, en la ejecución ulterior al monitorio el ejecutado podrá ejercer su derecho de defensa, la naturaleza del título ejecutivo cobra especial significación. Es así porque según se trate de un título ejecutivo judicial o extrajudicial el ámbito posible de esta oposición será diverso, en el segundo caso más amplio. En efecto, conforme al art. 406.XI ACPC "las excep- 
ciones que se opongan respecto de una obligación contenida en una resolución judicial o arbitral de condena o que apruebe una transacción o acuerdo logrado en el proceso, deberán fundarse en hechos acaecidos con posterioridad a la resolución, transacción o acuerdo cuyo cumplimiento se solicita". Como no se hace una referencia a cuál es el título ejecutivo, salvo que hagamos un extraordinario esfuerzo imaginativo, en el texto del ACPC queda en la total indefinición si la oposición va a ser posible y en tal caso el ámbito de la misma, concretamente si las excepciones habrán de fundarse o no en hechos acaecidos con posterioridad "a la resolución".

Por lo expuesto, el legislador habrá de aclarar como mínimo cuál es el ámbito exacto de la oposición, siempre que esta sea admisible, por supuesto. En mi opinión, todo esto se solucionaría si se quiere dotar al monitorio del carácter de verdadero proceso con toda su eficacia, simplemente disponiendo que partiendo de la actitud pasiva del deudor, no pagando ni dando razones para no pagar, no solamente procederá dictar mandamiento de ejecución y embargo, sino que este mandamiento equivaldrá a una tácita sentencia condenatoria y firme, con eficacia de cosa juzgada y valor de título ejecutivo.

\section{CONSIDERACIONES DE DETAlle SOBRE ALGUNOS ASPECTOS EX- PRESAMENTE REGULADOS}

Descendiendo algo más al detalle, algunos puntos expresamente regulados creo que merecen ser de algún modo "pulidos", sobre todo previendo las posibles disfuncionalidades que pueden producirse cuando se lleven a la práctica. Sin ánimo de exhaustividad, al menos merecen alguna atención los siguientes:

\section{Competencia (art. 506 ACPC)}

El art. 506 ACPC impone que será exclusivamente competente para conocer del proceso monitorio el Juez de Primera Instancia de la comuna en que se ubique el domicilio o residencia del deudor o, si no fueren conocidos, el del lugar en que el deudor pudiera ser hallado a efectos de requerimiento de pago por el "tribunal". A tal efecto se excluyen las reglas sobre prórroga de la competencia "consagrada" 15 en el párrafo 8 del Título VII del Código Orgánico de los Tribunales.

\footnotetext{
15 En mi opinión, un código moderno habría de evitar en la medida de lo posible términos que, aunque sean habituales en ámbitos jurídicos, contengan reminiscencias religiosas o litúrgicas.
} 
Su importancia trasciende al propio procedimiento monitorio, puesto que no solamente la atribuye para el mismo, sino también indirectamente, por venir atribuida funcionalmente conforme a este, para el proceso ulterior a la oposición y para el juicio ejecutivo que eventualmente proceda si no hay pago ni oposición admisible.

Este precepto desde luego guarda todas las similitudes, incluso lingüísticas, con el art. 813 LEC. Veamos:

Art. 506 ACPC. Será exclusivamente competente para conocer del proceso monitorio el Juez de Primera Instancia de la comuna en que se ubique el domicilio o residencia del deudor o, si no fueren conocidos, el del lugar en que el deudor pudiera ser hallado a efectos del requerimiento de pago por el tribunal. No serán aplicables en ningún caso las reglas sobre prórroga de la competencia consagrada en el Párrafo 8 del Titulo VII del Código Orgánico de Tribunales.

Art. 813 LEC. Será exclusivamente competente para el proceso monitorio el Juez de Primera Instancia del domicilio o residencia del deudor o, si no fueren conocidos, el del lugar en que el deudor pudiera ser hallado a efectos del requerimiento de pago por el tribunal... En todo caso, no serán de aplicación las normas sobre sumisión expresa o tácita contenidas en la Sección $2^{a}$ del Capítulo II del Título II del Libro I.

Es previsible, por tanto, que en su aplicación origine problemas prácticos similares cuando no idénticos a los que se han venido planteando en la práctica española.

Lo primero que ha de decirse es que el pretendido carácter imperativo o "absoluto" de la atribución competencial que deriva de esta norma, en cuanto excluye la aplicación de la sumisión, resulta más que discutible, sobre todo si su control a instancia de parte ha de articularse exclusivamente mediante declinatoria como parece. En efecto, sin perjuicio de su control de oficio, el art. 126.I ACPC impone que la declinatoria se promueva antes de hacer cualquiera otra gestión principal en el pleito, en este caso, la oposición, pues de lo contrario el incidente "será rechazado de plano por el tribunal". Salvo que a través de un hipotético control de oficio pudiera remediarse, por la vía de la preclusión impuesta en el citado art. 126 llegaremos a un efecto similar al de la sumisión tácita para fijar la competencia territorial.

De todos modos, la importancia de esta especie de "sumisión" por vía de la preclusión se mitiga de algún modo en la práctica si atendemos, en primer lugar, a que subsidiariamente la competencia se atribuye al lugar en que pudiere ser hallado (art. 506 ACPC); y, en segundo lugar, a que "solo podrá notificarse al deudor personalmente en conformidad con lo dispuesto en el artículo 85 de este Código" (art. 511.II ACPC). La propia existencia del requerimiento de pago válido por el juez de la comuna en la 
que el deudor ha sido notificado implicará que este ha podido ser efectivamente hallado. En el peor de los casos, se estaría atribuyendo así competencia al lugar previsto subsidiariamente en lugar de a los preferentes del domicilio o residencia cuando estos no sean coincidentes.

De otro lado, el que la competencia territorial se atribuya en función del domicilio, residencia o, subsidiariamente, lugar en que pudiera ser hallado implicará que su atribución esté condicionada a que se hubiera practicado una diligencia de notificación positiva. En caso contrario, salvo que sea por causa sobrevenida a la formulación de la petición (perpetuatio jurisdictionis que viene a ser reconocida por el art. 249.II ACPC ${ }^{16}$ ), o sea por causa imputable al propio deudor, el órgano jurisdiccional habría de considerarse incompetente. Tal situación es perfectamente posible. Nada impide que el acreedor señale varios lugares de domicilio, residencia o lugar en que pudiera ser hallado (de hecho el art. 508.2 se refiere al domicilio o domicilios del deudor); y que alguno de ellos se encuentre fuera del ámbito territorial del juzgado de primera instancia ante el que se presenta la petición. En tal caso, el juez habrá de intentar el requerimiento, condicionando su competencia a que se practique una notificación positiva. $\mathrm{Y}$ si se concluye que el domicilio o residencia reales se encontraban fuera de su ámbito territorial con anterioridad a la presentación de la petición de inicio del procedimiento, habría de considerarse incompetente.

Por último, ha de llamarse la atención sobre la imprevisión-mimética con el art. 813 LEC- sobre la posibilidad de que sean varios los deudores. La utilización siempre en singular al referirse al deudor y la ausencia de otra alusión específica podría conducir a entender que el procedimiento monitorio no es apto para los supuestos de pluralidad de partes al menos en la posición pasiva. Salvo mención en contrario, no creo que esta pueda ser la voluntad del legislador, de modo que se hace imprescindible que el art. 506 ACPC supere la redacción del art. 813 LEC incluyendo una previsión por la que, en caso de que sean varios los deudores, se atribuya competencia territorial al juzgado de primera instancia de la comuna en la que se ubique el domicilio o residencia de cualquiera de los deudores o, si no fueren conocidos, el del lugar en que alguno de ellos pudiera ser hallado (o quizá todos) a efectos del requerimiento de pago por el tribunal.

\section{2. Ámbito de aplicación (art. 507 ACPC)}

De modo similar a lo previsto en el art. 812 en relación con el 520, ambos LEC, en el que se exige para la admisibilidad del monitorio que

16 Según este precepto, "la competencia inicial no se modificará aunque posteriormente se alteren las circunstancias que la determinaron". 
la deuda sea "dineraria, vencida y exigible, de cantidad que no exceda" de una determinada cantidad, el art. 507 en relación con el 395, ambos ACPC, exigen que "las deudas" consistan en una cantidad líquida de dinero efectivo, expresada en moneda nacional, que se encuentren vencidas y sean actualmente exigibles, que la cantidad total de la o de las deudas cuyo cobro se solicita no exceda de 100 UTM, y que la deuda cuyo pago se reclama no se encuentre prescrita.

En primer lugar he de hacer una puntualización terminológica. Tanto en el art. 507 como en el art. 395 ACPC hablan de que la obligación no se encuentre "prescrita". Y a su vez, el art. 397 del mismo dispone que "la acción ejecutiva prescribirá si no se interpone la correspondiente demanda ejecutiva dentro de los tres años contados desde la fecha en que la obligación contenida en el título ejecutivo se hiciere exigible". Aunque tengan elementos comunes, se encuentra suficientemente asentado en la doctrina y en la jurisprudencia que caducidad y prescripción no son términos sinónimos ${ }^{17}$. Entre otras cosas y además de que la caducidad se suspende y la prescripción se interrumpe, se diferencian en que la primera es apreciable de oficio y la segunda a instancia de parte. Posiblemente convendría reconsiderar si lo que se pretende es que todo plazo previsto legalmente -sea de prescripción o de caducidad-represente un requisito para la admisibilidad del monitorio y por tanto sea siempre controlable de oficio, o si en realidad solamente se está exigiendo como requisito que, en relación con el citado art. 397, no haya pasado el plazo de caducidad de tres años desde que la obligación se hubiera hecho exigible.

17 Como indica la SAP Castellón (Secc. $3^{a}$ ), 19 enero 2001. Ponente: D. José Manuel Marco Cos. AC 2001/303, "a diferencia de la prescripción, la caducidad afecta a derechos que la Ley concede con vida ya limitada de antemano, por lo que se extinguirán fatalmente cuando haya transcurrido el plazo que se ba señalado. Conocido su momento inicial se sabe con certeza cuál va a ser el final, por lo que se dice que la caducidad es un becho simple, de fácil comprobación y puro automatismo, mientras que la prescripción es un becho complejo, por sus problemas de cómputo, interrupción, etc. (...). En suma, en la caducidad el tiempo fija el principio y el fin del derecho. De ello se deriva necesariamente que, a diferencia de la prescripción, la caducidad no es susceptible de interrupión, pues en ella el tiempo transcurre en forma inexorable, amén de que mientras la prescripción ha de ser alegada por la parte, la caducidad puede incluso ser apreciada de oficio. Estos criterios son los mantenidos en forma constante por la Jurisprudencia de la Sala Primera del Tribunal Supremo (...) Recogiendo los mismos, la Sentencia de 29 de mayo de 1992 señala que en la caducidad se atiende solo al becho objetivo de la falta de ejercicio dentro del plazo prefijado, hasta el punto de que puede sostenerse en realidad que es de indole preclusiva, al tratarse de un plazo dentro del cual y únicamente dentro de él puede realizarse un acto con eficacia juridica, de tal manera que transcurrido sin ejercitarlo se impone la decadencia fatal y automática de tal derecho en razón meramente objetiva de su no utilización". En fin, sobre la distinción entre prescripción y caducidad accesible en internet, ARIANO DEHO, E., "Prescripción" y código procesal constitucional (los mecanismos constitucionales de protección entre las garras del tiempo)", en bttp://www. bechosdelajusticia.org/quintalariano.rtf GALÁN SÁNCHEZ, R. Ma., "La caducidad de los procedimientos", en http://www.ucm.es/eprints/1455/01/ pon_6.pdf También, "La caducidad en los procedimientos de gestión y de inspección tributaria", en http://www.geocities.com/ariasvelascoleivissa.htm 
De otro lado, de nuevo he de indicar que el nivel de exigencia de los requisitos de la deuda que permita la apertura del procedimiento monitorio, mientras la obligación sea dineraria, determinada y exigible, no es tanto una cuestión técnica como una decisión de política legislativa. Resulta perfectamente aceptable desde este punto de vista que a diferencia de lo previsto en el derecho español y de modo similar a otros ordenamientos, la deuda no necesariamente haya de encontrarse documentada, exigiéndose solamente para que se proceda al requerimiento de pago que se cumplan los requisitos de los arts. 506 a 508 y estime el Juez como razonablemente justificado el cobro de la deuda (art. 510.I ACPC); o como también lo es que limite cuantitativamente el procedimiento en la cuantía que pueda entenderse prudente. Sin embargo, el nivel de exigencia de la deuda y las limitaciones que se impongan para su inicio pueden tener consecuencias en ámbitos que van más allá de los estrictamente procesales en cuanto podría estar en juego el establecimiento de un instrumento procesal capaz de ofrecer seguridad y confianza en el tráfico económico.

En mi opinión, el texto del ACPC se muestra excesivamente prudente al limitar la posibilidad de iniciar el procedimiento monitorio a las deudas expresadas en moneda nacional. Además de las consecuencias negativas que esta limitación podría tener sobre la confianza en las transacciones comerciales con elementos de extranjería, cada vez más comunes en una economía ascendente como es la chilena, esta aparente exclusión de las deudas en moneda extranjera contrasta con su admisibilidad en el ámbito del proceso de ejecución dineraria ${ }^{18}$. Esta sorprendente limitación, no obstante, podría mitigarse si se entiende correcto que la exigencia de la moneda nacional no lo sea en realidad de la "deuda" en sentido material, sino solamente en la forma en que esta se expresa. Y como no se requiere un soporte documental para que pueda entenderse como "razonablemente justificado el cobro de la deuda" por el juez (art. 507 en relación con el 510, ambos ACPC), bastaría con que se formule la petición inicial en moneda nacional previa la correspondiente conversión de la deuda en moneda extranjera.

\section{Petición inicial como verdadera demanda sucinta y postulación de las partes (arts. 508, 35 y 513 ACPC)}

En páginas anteriores me he referido a la denominación del escrito que inicia el monitorio como una cuestión simplemente lingüística. Los

18 Según el art. 421 ACPC, "si el título fijase la cantidad de dinero en moneda extranjera, se despachará la ejecución para obtenerla y entregarla... En el caso de que se trate de una moneda extranjera sin cotización oficial, el cómputo se hará aplicando el cambio que, a la vista de las alegaciones y documentos que aporte el ejecutante en la demanda, el tribunal considere adecuado, sin perjuicio de la ulterior liquidación de la condena". 
arts. 508 y 509 ACPC utilizan exactamente la misma denominación del art. 814 LEC, esto es, la de "petición inicial", evitando otra más técnica o precisa como podría ser la de "demanda sucinta".

Seguramente esta denominación menos técnica se explique en la vocación de que el procedimiento monitorio, el requerimiento de pago y el eventual cobro de la deuda, se instrumente directamente por el acreedor, sin la necesidad de integrar la capacidad de postulación (art. 508 in fine ACPC y 814.2 LEC). En el caso español incluso se prevé a tal efecto que la petición pueda extenderse en impreso o formulario que facilite la expresión de los extremos requeridos para su admisión (art. 814.1.II LEC).

Ahora bien, exactamente igual a lo que ocurre en derecho español (art. 814.1 en relación con el 437 LEC) ${ }^{19}$, la petición inicial tal y como se configura en el art. 508 ACPC en relación con el art. 383 del mismo, son perfectamente equivalentes. En efecto, conforme este último precepto, "el juicio sumario principiará mediante demanda sucinta, en la que se consignarán los datos y circunstancias de identificación del actor y del demandado y el domicilio o los domicilios en que pueden ser citados, y se fijará con claridad y precisión lo que se pida". Si lo comparamos con los requisitos de la petición de requerimiento de pago del art. 508 ACPC, la única diferencia significativa es que inexplicablemente (tanto como lo es esta ausencia en el art. 814 LEC) no se contiene la necesidad de hacer constar la identidad del acreedor, sino solamente su firma.

Posiblemente es así porque se presupone y se considera como obvio que si un acreedor formula una petición de inicio del procedimiento monitorio va a identificarse, sobre todo si se exige expresamente que el escrito contenga su firma. Sin embargo, no estaría de más que un definitivo CPC no incurriera en los mismos "errores" de la LEC española, de modo que por muy obvio que pueda resultar (tanto como que la petición ha de ser firmada o que conste la identidad del requerido) se exigiera expresamente que la petición contenga tal y como más correctamente hace el art. 383 (igual que el equivalente español art. 437 LEC), la identidad del acreedor.

En cualquier caso, resulta claro que la petición de inicio del procedimiento monitorio del art. 508 ACPC y la demanda sucinta del art. 383 del mismo, son perfectamente equivalentes. Una manifestación de la naturaleza de demanda es que el art. 511.II ACPC, por la notificación del requerimiento se dará lugar a la litispendencia, que es el efecto inmediato

Según este precepto, se iniciará el monitorio con la "petición del acreedor en la que se expresarán la identidad del deudor, el domicilio o domicilios del acreedor y del deudor o el lugar en que residieran o pudieran ser hallados y el origen y cuantía de la deuda, acompañándose el documento o documentos a que se refiere el artículo $812^{\prime \prime}$. 
de la demanda en todo proceso $^{20}$. Sus únicas diferencias es que en el primero se pretende darle un aspecto externo más sencillo, en cuanto no va a ser preceptiva la postulación, y como se ha indicado, se espera que sea el propio acreedor quien "gestione" el monitorio.

El repetido art. 508.I ACPC puede mejorarse eliminando alguna errata como lo es hablar de "el requerimiento de pago" en lugar de lo correcto que sería "la petición de requerimiento de pago" o sencillamente la "petición inicial". Y también podría mejorar si en lugar de mimetizar la terminología en ocasiones poco técnica de la LEC, se denominara a las cosas por su nombre y como por cierto denomina en el art. 35 a) ACPC, en este caso como "demanda sucinta", máxime cuando evitar esta denominación sirve de argumento para quienes opinan que el monitorio no es un verdadero proceso ${ }^{21}$.

De otro lado, a pesar de las reticencias que inicialmente mantuvieron los colegios profesionales españoles, ha de considerarse como adecuado que no sea precisa la integración de la postulación para la formulación de la petición inicial (o demanda sucinta) de procedimiento monitorio, puesto que para redactar dicha petición-demanda, explicar el origen de la deuda y hacer constar los datos identificadores de las partes, indicando que el juez siga los trámites previstos por la ley para el procedimiento monitorio y, por último, en el mejor de los casos, cobrar, no parece que sea necesaria la actuación de abogado alguno.

Por el contrario, resulta inexplicable que se exija la firma de abogado habilitado en el escrito de oposición (art. 513.II ACPC), si atendemos a que para su admisibilidad solamente se exige el respeto de unas ciertas formalidades y de unos tiempos (art. 514.I ACPC); su admisión no abre litigio alguno, sino que sencillamente lo cierra de forma casi automática sin ninguna otra exigencia material ni consecuencia; y sobre todo, cuando como hemos visto el acreedor no ha tenido que comparecer con la "designación de apoderado" pues los arts. 508 y 35 ACPC exceptúan de la regla general de comparecer al proceso asistido por abogado la presentación de la llamada en este último precepto "demanda monitoria", lo que contrastaría con el principio de igualdad de armas procesales al que se refiere expresamente el art. 7 ACPC.

20 Desde un punto de vista legislativo, el art. 410 LEC es claro cuando dispone que "la litispendencia, con todos sus efectos procesales, se produce desde la interposición de la demanda, si después es admitida". Y según su equivalente en el art. 249 ACPC, "la demanda formalmente idónea determina la litispendencia desde la fecha de su presentación".

21 Véase un ejemplo de utilización de esta terminología en GÓNZÁLEZ LÓPEZ, R., "Sobre la debarida naturaleza jurídica del proceso monitorio", en bttp://www.derecho.com/boletin/articulos/articulo0108.btm 


\section{Admisión o no de la petición inicial (art. 509 ACPC)}

Solamente tres cuestiones sobre este precepto, una estrictamente terminológica y otras dos algo más de fondo.

En primer lugar, destaca la utilización del término "desestimar" cuando en el art. 509 se refiere más bien a la fase de rechazo o no admisión (y solamente sensu contrario de admisión) de la petición inicial. Ciertamente que las palabras "inadmitir" e "inadmisión" en sus diversas modalidades, por más que se utilicen reiteradamente en el texto de la LEC española ${ }^{22}$ y sea más o menos habitual en la literatura jurídica ${ }^{23}$, no se encuentran reconocidas por la Real Academia de la Lengua y, por mucho que se busquen, no las encontraremos en su diccionario. Sí que se encuentra en cambio el término "admisión" como "trámite previo en que se decide, atendiendo a aspectos de forma, si una demanda o recurso deben pasar o no a ser resueltos en cuanto al fondo", acepción precisamente cuyo antónimo es el que procede ser utilizado en este precepto. Por supuesto que la palabra desestimar sí se encuentra en el mismo Diccionario con el escueto y bastante aséptico significado de "tener a poco" o "denegar, desechar". No obstante, en el ámbito forense el término desestimar evoca a una decisión no por aspectos formales sino más bien de fondo. Y de hecho el propio ACPC en otros supuestos utiliza correctamente los términos estimar o desestimar con ocasión de decisiones siempre de fondo ${ }^{24}$. En fin, puesto que en este trámite no se entra en cuestiones de fondo ${ }^{25}$, en mi opinión, resultaría menos confuso y más preciso que se utilizara un término acorde con la naturaleza estrictamente formal de la decisión, por ejemplo, hablando de "rechazo" o simplemente, de "no admisión" de la petición inicial.

$22 \mathrm{Al}$ menos, en los arts. 79.1, 107.1, 122, 206, 228.1.III, 225.4, 272, 368, 369, 372, 392, $403.1,439,446,452$. II, 473.1 y 2.2 $2^{\circ}$.II y III, 483, Disp. Fin. Decimosexta 1.5”, y hasta en la Exposición de Motivos de la LEC.

23. Valga como ejemplo el título del siguiente trabajo: MARTín BRAÑAS, C., "Inadmisión de prueba pericial: Proposición con anterioridad a la celebración del juicio oral; inadmisión sin perjuicio de su posible práctica para mejor proveer: Redacción confusa frente a falta de diligencia: Existencia de indefensión para la parte: Voto", en Tribunales de Justicia, núm. 6, 2000, pp. 745-51

24 Así, por ejemplo, el art. 410 ACPC con ocasión de la resolución que resuelve sobre la oposición por motivos de fondo, se refiere a que se declarará "procedente que la ejecución siga adelante... cuando la oposición se desestimare totalmente", o también que "la resolución que desestime totalmente la oposición condenará en las costas de esta al ejecutado"; igualmente el art. $484 \mathrm{del}$ mismo, habla de que "si la sentencia desestimara la tercería condenará en todas las costas de esta al tercerista. Cuando la estimare, las impondrá al ejecutante que hubiera contestado a la demanda..."

Hasta el punto es así que el art. 510.1 ACPC exige que el requerimiento de pago conrenga "la advertencia de que el Tribunal no ha examinado la justificación de la deuda antes de despachar el requerimiento de pago". 
En segundo lugar, de nuevo se muestra el texto cauto frente al inicio del procedimiento monitorio pues señala que no se admitirá la petición inicial "cuando el requerimiento de pago no pueda ser emitido por la totalidad de la deuda" (art. 509.2 ACPC). Posiblemente el sentido y fin de esta prevención sea garantizar el debido cumplimiento del límite cuantitativo máximo (art. 507.3 ACPC), evitando al tiempo fraudes de ley por los que se parcele una misma deuda y se permita por esa vía instrumentar varios procedimientos monitorios para la misma obligación. Sin embargo, no alcanzo a comprenderlo cuando el resto no posible del total consista en partidas accesorias. Desde luego, no parece que esta expresión impida que el acreedor renuncie a una parte de la deuda, precisamente a la que exceda del límite máximo, pues en tal caso, la deuda se reduciría a la parte no renunciada y de ese modo podría ser emitido el requerimiento por la totalidad.

En tercer lugar, en cuanto al sistema de recursos, se prevé que "en contra de la resolución que desestime la petición inicial no procederá recurso alguno, salvo la reposición ante el mismo Tribunal". Ciertamente esta norma entra en relación con las normas generales de los arts. 345 y $346 \mathrm{ACPC}^{26}$ y el art. $514 \mathrm{ACPC}$ no prevé que se dicte sentencia alguna, sino "resolución". Este "sistema" de impugnación limitada representa una nueva muestra de las excesivas prevenciones y limitaciones frente a la operatividad práctica del procedimiento monitorio. Si contamos con que la estadística demuestra las dificultades que se producen para que un juez reconsidere su propia decisión previa, cabe prever que los errores e indebidos rechazos de la petición inicial serán difícilmente subsanados y controlados eficazmente mediante la reposición. Cabe preguntarse qué mecanismos de protección corresponderán al acreedor frente a un concreto juez que, sin perjuicio de otros motivos menos confesables, se empecine en sus propios errores interpretativos de los motivos de rechazo de todas las peticiones iniciales o hasta exclusivamente las de un mismo acreedor. Si el "recurso" frente a la decisión de rechazo no está dotado de efecto devolutivo, se carecerá de forma ordinaria y verdaderamente eficaz para controlar y corregir posibles errores y desviaciones de poder. Y en este punto nos encontramos ante materia tan "sensible" como la admisión del procedimiento monitorio y, por tanto, del derecho de acceso a los tribunales con todas las garantías que el ordenamiento jurídico ofrece.

26 Según el art. 345 "serán inapelables las resoluciones dictadas por un tribunal de primera instancia, a menos que una norma especial contemple la procedencia de ese recurso"; y el art. 346 limita la apelación a "las sentencias definitivas y las sentencias interlocutorias de primera instancia, siempre que pongan término al juicio o hagan imposible su continuación, las resoluciones que ordenen el pago de costas por un monto superior a 100 UTM, y las que se pronuncian sobre el otorgamiento, rechazo, modificación y alzamiento de medidas cautelares". 
Creo por lo expuesto que esta materia merece superar el substrato de prevención que se vislumbra frente a un desconocido por novedoso procedimiento monitorio, y otorgar la posibilidad de articular un medio de impugnación eficaz frente a la decisión de rechazo de la petición inicial como sería un recurso devolutivo, esto es, el de apelación (art. 350 ACPC).

\section{El requerimiento de pago y su notificación (arts. 510 y 511 ACPC)}

La redacción del art. 510 resulta en algún punto contradictoria con sus propios términos. Primero nos indica que si, entre otras cosas, "estima el juez como razonablemente justificado el cobro de la deuda, despachará requerimiento de pago..." y a continuación en el mismo requerimiento ha de contenerse la advertencia de que "el Tribunal no ha examinado la justificación de la deuda antes de despachar el requerimiento de pago".

Una vez más se vislumbra la prevención excesiva del redactor frente al procedimiento monitorio. Parece como si se pretendiese advertir al deudor de que no tiene por qué pagar realmente pues el tribunal le requiere por meras apariencias, de modo que con el requerimiento parece soterradamente incentivarse más la oposición que el pago. Posiblemente se pretende dejar constancia de que se ordena el pago solamente partiendo de entender razonablemente justificado el cobro de la deuda, por tanto, sin que se haya adoptado en ese momento decisión declarativa sobre su existencia ni por tanto de condena para su cumplimiento. Pero desde luego resulta bastante desafortunado afirmar que se ha estimado razonablemente justificado el cobro de la deuda y advertir acto seguido que no ha examinado la justificación. Parece ineludible aclarar y pulir la redacción en este punto.

Por lo demás, solamente poner de manifiesto el acierto de que expresamente se deje sentado, diversamente a la imprevisión de la LEC en este punto ${ }^{27}$ y aunque sea de modo innecesariamente reiterado en los

27 No obstante la imprevisión legislativa y aunque algunos autores todavía mantengan la posibilidad de norificación no personal en el proceso monitorio, la doctrina mayoritaria ha tenido que tomar partido por la exclusión de esta posibilidad. En este sentido, entre otros, Serra Domínguez, M., La Ley 1/2000 sobre Enjuiciamiento Civil, Bosch, Barcelona, 2000, pp. 58 y ss. LÓpez SÁnCHez, J., El proceso monitorio, La Ley, Madrid, 2000, p. 202. Correa Delcasso, J. P., El proceso monitorio en la nueva Ley de Enjuiciamiento Civil. Marcial Pons, Madrid, 2000, p. 178. Diez-PiCAzo Giménez, I., "Del proceso monitorio", en Comentarios a la Ley de Enjuiciamiento Civil, (con DE LA Oliva, Vegas y BANACloche), Civitas, Madrid, 2001, pp. 1367-8. GArberí, Torres y CAsero, El cobro ejecutivo de las deudas en la nueva Ley de Enjuiciamiento Civil, Bosch, Barcelona, 2002, pp, 1180 y 1187. PICÓ I JunOY, J., "Los requisitos constitucionales del emplazamiento edictal y la nueva 
párrafos I y II del art. $511 \mathrm{ACPC}$, que la notificación del requerimiento se realice solo personalmente como concreción de la regla general contenida en el art. 85 del mismo ACPC.

\section{6. "Incomparecencia" del deudor e innecesariedad de demanda ejecutiva (art. 512 ACPC)}

En el título del art. 512 ACPC, intentando resumir su contenido, se incurre en la misma imprecisión del art. 816 LEC, pues se habla de incomparecencia del deudor como provocadora del ulterior despacho de la ejecución. Ahora bien, al contrario de lo que ocurre en la LEC, el citado art, 512 redacta el precepto con alguna mayor precisión, al disponer que "si el deudor requerido no presentare oposición o si esta fuere rechazada por el Tribunal por no cumplir con algún requisito de forma o por presentarse fuera de plazo, este dictará mandamiento de ejecución y embargo...". De un lado, es claro que este mandamiento será procedente no solo por la "incomparecencia" del deudor, sino también cuando se limite a comparecer y no haga nada más. Ahora bien, olvida esta redacción que tampoco procederá el mandamiento de ejecución cuando la situación descrita se produzca por el sencillo motivo de que el deudor hubiera cumplido el requerimiento pagando la total cantidad debida. Se hace, por tanto, necesario que se modifique la redacción para que no parezca como se desprende de la equívoca redacción del art. 512 ACPC que no obstante haberse pagado procederá el mandamiento de ejecución y embargo.

Otro problema de cierto calado se produjo en el derecho español por la omisión (art. 816 LEC) de una previsión específica sobre si debía formularse o no demanda ejecutiva. Tal omisión, relacionándola con la regla general de que el juicio ejecutivo se inicia con demanda ${ }^{28}$, provocó

Ley 1/2000 de Enjuiciamiento Civil”, en Revista Jurídica de Catalunya, núm. 3, 2000, pp. 85-105. Hinojosa Segovia, R., "Algunas cuestiones polémicas en la aplicación de los procesos monitorio y cambiario", en Revista de Derecho Procesal, núms. 1 y 2,. 2002, pp. 305-6. Bonet Navarro, J., "La nueva tutela judicial del crédito y su incidencia en el derecho a un proceso sin indefensión", en Presente y futuro de la Constitución española de 1978, Tirant lo Blanch, Valencia, 2005, pp. 121-34. Y lo mismo en la jurisprudencia mayoritaria, por ejemplo, SAP Vizcaya, (Secc. $3^{a}$ ), 28 julio 2003. Ponente: Dña. Ana Isabel Gutiérrez Gegúndez. AC 2003\1799, si bien con alguna excepción como AAP Valencia, 7 noviembre 2001, SP/AUTO/507, comentada en sentido crítico por SEPIN, "Juicio monitorio: inadmisión de la demanda por no aportarse documento original acreditativo de la deuda", SEPIN, LEC, Forum, Ley de Enjuiciamiento Civil, núm. 19, mayo 2002, pp. 63-4.

28 Por lo que se refiere a la LEC, el art. 549.1 dispone que "solo se despachará ejecución a petición de parte, en forma de demanda, en la que se expresarán..." Y en la misma línea y casi idéntica redacción, el art. 399 ACPC indica que "solo se despachará ejecución a petición de partes, en forma de demanda, la que contendrá además de los requisitos previstos en el artículo 242 , los siguientes..." 
que algunos juzgados de primera instancia españoles, incluso en ocasiones por acuerdos de juntas de jueces, tras constatar que el deudor no había pagado ni formulado oposición, en lugar de dictar auto despachando ejecución como le ordena taxativamente el art. 816 LEC (mandamiento de ejecución y embargo de oficio según el art. 512 ACPC), empezaron a dictar providencia requiriendo al acreedor para que formule la correspondiente demanda ejecutiva ${ }^{29}$. No obstante, esta práctica incumplidora del rigor con que regula el art. 816 LEC, que ante la "incomparecencia" del deudor imponía el despacho de la ejecución, con el tiempo fue cediendo gracias a la doctrina de las Audiencias Provinciales ${ }^{30}$, fundada en otra posición doctrinal diametralmente opuesta basada principalmente en la dicción literal del mismo art. 816 LEC. Y mientras tanto tuvo que producirse un importante esfuerzo doctrinal, y también personal para unas partes perplejas porque según el juzgado que se tratase tenían que formular o no demanda ejecutiva.

Ante ello, ha de resaltarse que el art. 512 ACPC soslaya una buena parte de la problemática que se ha planteado en España, pues deja bien claro que el mandamiento de ejecución y embargo será dictado de oficio por el "Tribunal". Y ello contando con que la formulación de demanda ejecutiva plantea importantes ventajas, tanto dogmáticas en lo que se refiere al principio dispositivo no obstante la posibilidad de sus excepciones (art. 5 ACPC), como prácticas respecto a peticiones adicionales en la misma sobre intereses y costas de la ejecución, información sobre bienes del ejecutado susceptibles de embargo o en general todas las medidas de localización e investigación que interese. No obstante, estos inconvenientes prácticos que produce la ausencia de la demanda ejecutiva, creo que no impiden la excepción, pues para ello serán adecuados también escritos ad hoc; máxime cuando, además, forma parte de las características esenciales del proceso monitorio que la falta de actividad del deudor demandado, porque no paga o no formula oposición, suponga abrir expeditivamente el proceso de ejecución sin necesidad de realizar actividad procesal alguna. En definitiva, la redacción del art. 512 ACPC en cuanto aclara que se abrirá "de oficio" supera la regulación del art. 816 LEC y resulta correcta en general.

29 Para una referencia a las razones en que se basaba y su soporte doctrinal, véase, BONET NAVArRo, J., La reclamación judicial de los gastos de comunidad, cit., pp. 299-303, notas 575-90.

30 Entre otras muchas, AAP Granada (Secc. 4*), 22 diciembre 2005 (Ponente: D. Moisés Lazuen Alcón. JUR 2006/161935). AAP Cádiz (Secc, 8*), 8 enero 2004 (Ponente: Carmen González Castrillón. AC 2004/754). AAP Zaragoza (Secc. 5), 29 abril 2003 (Ponente: D. Antonio Luis Pastor Oliver. AC 2003/1249). AAP Valencia (Secc. 6 ${ }^{a}$ ), 30 sepriembre 2002 (Ponente: Dña. Carmen Tamayo Muñoz. AC 2002/1706). 


\section{Oposición del deudor y procedimiento ulterior (arts. 513 y 514 ACPC)}

A pesar de que la vinculación de la oposición con el ulterior proceso para sustanciarla sea de capital importancia para la utilidad y supervivencia práctica del procedimiento monitorio, no voy a reiterar una vez más la necesidad de articular preceptos que la garanticen, de modo que la oposición y finalización del monitorio tenga consecuencias para el deudor como la fijación material del objeto de la oposición y hasta posibles condenas en costas y sanciones por vulnerar la buena fe procesal (art. 8 ACPC). Igualmente, me remito a lo dicho sobre la postulación en el punto 3 de este mismo apartado. Me limitaré en este momento a resaltar otras cuestiones.

La oposición vendrá referida a las razones por las cuales el deudor no debe en todo o en parte la deuda. Sin embargo, cuando la oposición sea sobre una parte, no hay previsión alguna para que se proceda como la lógica impone: dictándose de oficio mandamiento de ejecución y embargo sobre la parte de deuda que no hubo oposición. De un lado, el art. 512 ACPC no ofrece matización alguna en este punto, pues habla de "si el deudor requerido no presentare oposición o si esta fuere rechazada" por razones formales o temporales se dictará mandamiento de ejecución; y de otro, el art. 514.I ACPC taxativamente impone la finalización del proceso monitorio por la formulación de oposición. Parece obvio que cabe interpretar correctamente que en caso de oposición parcial, en la parte que no hubo oposición, no cabrá finalización total del monitorio y por tanto procederá mandamiento de oficio de ejecución y embargo en la parte que no se haya formulado oposición o pago. No obstante conviene que se aclare la redacción en este punto en prevención de favorecer interpretaciones que por más ilógicas no dejarían de tener sustento normativo.

De otro lado, dice literalmente el art. 514.III ACPC que "cualquiera de las partes podrá iniciar ante el mismo Tribunal ante el cual se sustanció el monitorio el procedimiento ordinario que corresponda en razón de la cuantía de la oposición, rigiéndose dicho proceso en su totalidad por las normas contenidas en el Título I del Libro IV de este mismo Código". Como se observa, por un lado nos dice con total rotundidad que podrán iniciar el procedimiento ordinario que corresponda en razón de la cuantía de la oposición (supongo que la cuantía es la de la oposición y no la del total de la deuda para el caso de que se hubiera formulado oposición parcial), esto es, el "juicio ordinario" o el "procedimiento sumario" en función de que la cuantía supere o no "100 UTM", conforme el art. $382.14^{\circ}$ ACPC. Sin embargo, a continuación, nos indica que dicho proceso se regirá "en su totalidad por las normas contenidas en el Título I del Libro IV". Basta con observar el ACPC para comprobar que el Libro IV se refiere a "los procesos especiales" y el Título I del mismo regula el 
"procedimiento sumario". No se sabe bien si se trata de una norma particular aunque equívoca de adecuación de procedimiento por la materia; o más bien, como parece, de una simple errata, dada la contradicción del párrafo en sus propios términos. Resulta necesario que se revise este párrafo para que quedara clara esta cuestión en textos posteriores.

\section{EPÍLOGO Y RESUMEN A MODO CONCLUSIVO}

En su opción de configuración, el legislador chileno podrá otorgar al procedimiento monitorio las notas y características que considere oportuno. Por supuesto dentro de los elementos esenciales del mismo, pues de otro modo regularía otra cosa. Las posibilidades básicamente son dos: dotar al procedimiento monitorio el carácter de meros actos preparatorios de la ejecución, abocado tal y como se configura en la actualidad el procedimiento al más estrepitoso de los fracasos prácticos; o atribuirle la naturaleza de proceso de declaración con todas sus ventajas (cosa juzgada) y contando con elementos que impidan que el deudor convierta en unos meros trámites sin utilidad (vinculación de la oposición con el ulterior proceso). Esta segunda opción se presenta como la más conveniente. En cualquier caso, para mejorar la actual redacción de los arts. 506 a 514 ACPC, en mi opinión el legislador ha de atender, en síntesis, a lo siguiente:

$1^{\circ}$. El procedimiento monitorio requiere una revisión a fondo. En los términos del actual texto del ACPC refleja una poco clara definición conceptual, se encuentra desaprovechado y, de no modificarse, abocado al mayor de los fracasos en cuanto a su utilidad práctica.

$2^{\circ}$. Se hace urgente eliminar la previsión contenida en el actual art. 513.IV ACPC, estableciendo un mecanismo para que se produzca la adecuada vinculación de las razones contenidas en la oposición del deudor para no pagar con el objeto del proceso que corresponda para sustanciar esta oposición. De otro modo quedará desincentivada la "seriedad" de la oposición, y, por ese camino, abocando el monitorio a la inutilidad.

$3^{\circ}$. Es conveniente, para su mayor eficacia y seguridad jurídica, que el proceso monitorio que termine sin oposición ni pago esté dotada de eficacia de cosa juzgada. De lo contrario el deudor contará con dos oportunidades para aportar sus defensas. Y además así lo aconseja evitar los inconvenientes de una eventual restitutio in integrum provocada en definitiva por no haber formulado el deudor su oposición en la primera oportunidad con la que contaba.

$4^{\circ}$. Resulta conveniente aclarar el modo en que habrá de articularse en el seno del procedimiento monitorio la defensa del deudor basada en 
la falta de jurisdicción o de competencia en todas sus modalidades, sea mediante declinatoria o sea como excepción procesal que integrase la oposición.

$5^{\circ}$. Ha poderse conocer cuál es el título ejecutivo que se "crea" con la actitud pasiva del deudor. Esto no solamente por una mera precisión dogmática, sino más bien por una cuestión con tanta relevancia práctica como determinar el ámbito exacto de la oposición admisible en la ulterior ejecución. En mi opinión, el modo más adecuado sería añadiendo en el art. 512 ACPC que el mandamiento de ejecución y embargo equivaldrá a una tácita sentencia condenatoria y firme, con eficacia de cosa juzgada y valor de título ejecutivo.

$6^{\circ}$. Se hace imprescindible que el art. 506 ACPC incluya una previsión por la que, en caso de que sean varios los deudores, se atribuya competencia territorial al juzgado de primera instancia de la comuna en la que se ubique el domicilio o residencia de cualquiera de los deudores o, si no fueren conocidos, el del lugar en que alguno de ellos (o quizá todos) pudieran ser hallados.

$7^{\circ}$. Convendría reconsiderar si la alusión del art. 507 ACPC a la "prescripción" es correcta y si en realidad solamente se está exigiendo como requisito que se controle el plazo del art. 397 ACPC.

$8^{\circ}$. El mismo art. 507 ACPC se muestra excesivamente prudente al limitar la posibilidad de iniciar el procedimiento monitorio a las deudas expresadas en moneda nacional, con las consecuencias negativas que esta limitación podría tener sobre la confianza en las transacciones comerciales con elementos de extranjería, cada vez más comunes en una economía ascendente como es la chilena.

$9^{\circ}$. El art. 508.I ACPC mejoraría eliminando alguna errata como hablar de "requerimiento de pago" en lugar de lo más correcto "petición de requerimiento de pago" o sencillamente "petición inicial". Y también podría mejorar si en lugar de mimetizar la terminología en este caso del art. 814 LEC, denominara a las cosas por su nombre, en este caso como "demanda sucinta" al escrito de inicio del monitorio.

$10^{\circ}$. Resulta inexplicable que se exija la firma de abogado habilitado en el escrito de oposición (art. 513.II ACPC), si atendemos a que para su admisibilidad solamente se exige el respeto de unas ciertas formalidades y de unos tiempos (art. 514.I ACPC); su admisión no abre litigio alguno sino que sencillamente lo cierra de forma casi automática y sin ninguna otra exigencia material ni consecuencia; y sobre todo cuando el acreedor no ha tenido que comparecer con la "designación de apoderado", lo que contrastaría con el principio de igualdad de armas procesales al que se refiere expresamente el art. 7 ACPC.

$11^{\circ}$. Sería menos confuso y más preciso que en el art. 509 ACPC en lugar del término "desestimar" utilizara otro más acorde con la 
naturaleza estrictamente formal de la decisión, por ejemplo, hablando de "rechazo" o simplemente, de "no admisión" de la petición inicial.

$12^{\circ}$. Frente a la decisión de no admitir la "petición inicial" se habría de otorgar la posibilidad de articular un medio de impugnación eficaz y devolutivo, esto es, el recurso de apelación. De lo contrario, los errores e indebidos rechazos serán difícilmente controlados y subsanados, y no ha de olvidarse que nos encontramos ante materia tan "sensible" como la admisión del procedimiento monitorio y, por tanto, del derecho de acceso a los tribunales con todas las garantías que el ordenamiento jurídico ofrece.

$13^{\circ}$. Se ha de aclarar y pulir la redacción del art. 510 ACPC pues resulta contradictorio con sus propios términos cuando primero se refiere a que si "estima el juez como razonablemente justificado el cobro de la deuda, despachará requerimiento de pago..." y a continuación en el mismo requerimiento ha de contenerse la advertencia de que "el Tribunal no ha examinado la justificación de la deuda antes de despachar el requerimiento de pago".

$14^{\circ}$. La redacción del art. 512 ACPC ha de aclarar si remite al párrafo $2^{\circ}$ o en realidad remite al Capítulo $2^{\circ}$; igualmente convendría ser modificado para que no parezca que no obstante haberse pagado procederá el mandamiento de ejecución y embargo.

$15^{\circ}$. Convendría articular un mecanismo que cumpla con las funciones que en la práctica cumple la demanda ejecutiva como designar bienes, indicar medios de localización de los mismos, integrar la carga de la postulación, etc.

16. Convendría aclarar la redacción del art. 514.I ACPC en el sentido de que cuando se formule oposición por una parte de la deuda, no parezca en la literalidad del mismo que procederá en tal caso la finalización de todo el monitorio.

$17^{\circ}$. Ha de revisarse el art. 514.III ACPC puesto que parece contradictorio en sus términos. Nos dice primero que las partes podrán iniciar el procedimiento ordinario que corresponda en razón de la cuantía de la oposición y a continuación nos indica que dicho proceso se regirá "en su totalidad por las normas contenidas en el Título I del Libro IV", esto es, el juicio sumario.

\section{BIBLIOGRAFÍA}

- Ariano Deho, E., "Prescripción" y código procesal constitucional (los mecanismos constitucionales de protección entre las garras del tiempo)", en http://www. bechosdelajusticia.org/quintalariano.rtf GALÁN SÁNCHEZ, R. M ${ }^{a}$., "La caducidad de los procedimientos", en bttp:// 
www.ucm.esleprints/1455/01/pon_6.pdf También, "La caducidad en los procedimientos de gestión y de inspección tributaria", en bttp:// www.geocities.com/ariasvelascoleivissa. btm

La reclamación judicial de los gastos de comunidad, Edisofer, Madrid, 2004

- Bonet Navarro, J., "La relativa autonomía del "Juicio que corresponda" tras la oposición en los procedimientos monitorios", en Problemas actuales del proceso iberoamericano. XX Jornadas iberoamericanas de Derecho Procesal, I, Actas, CEDMA, Málaga, 2006, pp. 373-86.

, "La nueva tutela judicial del crédito y su incidencia en el derecho a un proceso sin indefensión", en Presente y futuro de la Constitución española de 1978, Tirant lo Blanch, Valencia, 2005.

- Correa Delcasso, J. P., El proceso monitorio en la nueva Ley de Enjuiciamiento Civil, Marcial Pons, Madrid, 2000.

- Díez-Picazo Giménez, I., "Del proceso monitorio”, en Comentarios a la Ley de Enjuiciamiento Civil (con DE LA Oliva, Vegas y BANAClOCHE), Civitas, Madrid, 2001.

- Garberí, Torres y Casero, El cobro ejecutivo de las deudas en la nueva Ley de Enjuiciamiento Civil, Bosch, Barcelona, 2002.

- GÓNzÁlez LÓPEZ, R., "Sobre la debatida naturaleza jurídica del proceso monitorio", en bttp://www.derecho.com/boletin/articulos/ articulo0108. htm

- Hinojosa Segovia, R., "Algunas cuestiones polémicas en la aplicación de los procesos monitorio y cambiario", en Revista de Derecho Procesal, núms. 1 y 2, 2002.

- López SÁnchez, J., El proceso monitorio, La Ley, Madrid, 2000.

- Martín BRAÑAS, C., "Inadmisión de prueba pericial: Proposición con anterioridad a la celebración del juicio oral; inadmisión sin perjuicio de su posible práctica para mejor proveer: Redacción confusa frente a falta de diligencia: Existencia de indefensión para la parte: Voto", en Tribunales de Justicia, núm. 6, 2000.

- Ortells Ramos, M., Derecho Procesal Civil, (con Mascarell, Cámara, Juan, Bonet, Cucarella, Bellido y Martín), ThomsonAranzadi, 6a ed., Cizur Menor, 2005.

- Pérez Ragone, A. J., "En torno al procedimiento monitorio desde el Derecho Procesal comparado europeo: caracterización, elementos esenciales y accidentales", en Revista de Derecho Universidad Austral de Chile, Vol. XIX, núm. 1, julio 2006, págs. 205-35. http://www.scielo. $\mathrm{cl} /$ scielo.php? script $=$ sci_arttextEpid $=$ S0718-09502006000100009 $\mathcal{E} \operatorname{lng}=$ es $\mathcal{E} n r m=i s o \mathcal{E} t \operatorname{lng}=e s \# n 42$

- PiCó I JUNOY, J., "Los requisitos constitucionales del emplazamiento edictal y la nueva Ley 1/2000 de Enjuiciamiento Civil”, en Revista Jurídica de Catalunya, núm. 3, 2000. 
- SePIN, "Juicio monitorio: inadmisión de la demanda por no aportarse documento original acreditativo de la deuda", SEPIN, LEC, Forum, Ley de Enjuiciamiento Civil, núm. 19, mayo 2002.

- Serra Domínguez, M., La Ley $1 / 2000$ sobre Enjuiciamiento Civil, Bosch, Barcelona, 2000. 